\title{
UF

\section{Procedure for Handling 4-H Accounts: Tax-Related Procedures for 4-H Clubs and Affiliated Groups $^{1}$}

Marilyn Norman and Joy C. Jordan ${ }^{2}$

An authorized chartered 4-H club or other 4-H affiliated group with a treasury account is subject to both state and federal laws and regulations, including tax laws. The guidelines below are provided as an overview of these laws. Specific information regarding individual circumstances will require additional consideration. Understanding the general tax implications will assist volunteers and staff in proper financial transactions, fundraising, and reporting.

\section{Federal Income Tax Exemption}

4-H Clubs and Affiliates who have been authorized to use the 4-H Name and Emblem and have treasuries with an IRS Employer Identification Number (EIN) using the Group Exemption Number (GEN) 2704 are exempt from paying federal income tax. These groups do have a legal responsibility to report their income on an IRS Form 990 if it reaches or exceeds $\$ 25,000$ in a calendar year.

Current IRS publications covering tax-exempt status should be reviewed annually for details on reporting requirements and changes in the code.

The Internal Revenue Service has recognized the tax-exempt status of 4-H units and affiliated 4-H organizations which are organized and operated under the auspices of Cooperative Extension. This guidance and oversight must be in keeping with the regulations governing the use of the $4-\mathrm{H}$ name and emblem, and be in accordance with the policy statement in Chapter XI, Section 8.2 of the Federal Administrative Handbook for Cooperative Extension work.

One publication that can help Cooperative Extension personnel interpret the authorization is "Tax Exemption Status of 4-H Clubs and Affiliated 4-H Organizations." It can be found at http://www.national4-hheadquarters.gov/ or by contacting the state or county $4-\mathrm{H}$ program office.

\section{Getting on the IRS Cumulative List (of Charitable Organizations)}

Upon being contacted about making a contribution to a 4-H Club or affiliate, many large organizations or private groups will check IRS Publication 78, Cumulative List of Organizations described in Section 170(c) of the Internal Revenue Code of 1986. This publication, available both online and as a printed document, is a list of organizations eligible to receive tax-deductible charitable contributions. It can be viewed on the Web at http://www.irs.gov/charities/article/ 0, ,id=96136,00.html.

To be listed in Publication 78, 4-H Clubs and affiliates need to provide the group EIN (Employer Identification Number) to the Extension Office for an annual update to the IRS.

\footnotetext{
1 This document is 4H 5.7/4H257, one of a series of the Florida 4-H Program, Florida Cooperative Extension Service, Institute of Food and Agricultural Sciences, University of Florida. First published February 2007. Revised January 2008. Please visit the 4-H Website at http://4h.ifas.ufl.edu/Curriculum/index.htm.

2 Marilyn Norman, Associate Professor in the Department of Family, Youth and Community Sciences and State 4-H Program Leader, and Joy C. Jordan, Associate Professor in the Department of Family, Youth and Community Sciences, Institute of Food and Agricultural Sciences, University of Florida, Gainesville. 
Receiving Donations of Gifts, Property, Equipment, or Animals

As determined by the Internal Revenue Service (IRS), donors may deduct contributions to 4-H clubs and affiliated 4-H organizations. This can include bequests, legacies, devises, transfers, or gifts, as applicable under the IRS Code. Most donors will request documentation of the gift on letterhead paper. The tax documentation letter should include the date, the name of the organization, the EIN, a description of the gift (do not provide a value unless it is cash), and the specifications for the unrestricted or restricted use of the gift, as defined by the donor.

Due to IRS regulations surrounding donated animals, it is not recommended (for tax purposes) to accept the donation of any live animal.

\section{Florida Sales Tax Exemption}

A Florida nonprofit, such as a 4-H Club or affiliate, may apply to the Florida Department of Revenue to receive a certificate of exemption from sales tax on things purchased that further the mission of the nonprofit. This exemption is not automatically granted just because a group is exempt from federal income tax.

A 4-H Club or affiliate must apply through the Florida Department of Revenue. Form DR-5 must be completed. This form is available online through the Department at http://dor.myflorida.com/dor/forms/ 2003/dr5.pdf /2003/dr5.pdf. The process takes several weeks. This certificate must be renewed periodically.

The best way to use a Florida sales tax exemption is to establish a charge account with any companies you do business with on a regular basis. They will ask for a copy of your certificate. The exemption can only be taken when you pay the company with an authorized check from your foundation/county/club/affiliate account.

The exemption is only good when materials are purchased with a foundation/county/club/affiliate (whatever entity has filed and received a certificate of tax exemption) check. For instance, if a volunteer were to go to a local business to buy paper supplies for the 4-H banquet, he or she could not write a personal check and still be granted the sales tax exemption. The sales tax exemption is valid only for the entity that specifically applies for it. All purchases must be paid for with monies from a nonprofit entity — not money of an individual. The Florida Department of Revenue will penalize any organization sharing a sales tax exemption number.

Companies wanting to verify the name and certificate number of 4-H groups holding the Florida Department of Revenue Certificate can perform an online search at https://suntax.state.fl.us/irj/ portal/anonymous.

The University of Florida is a qualifying governmental body exempt from paying Florida sales tax on purchases for its own use, as are county governments. Extension Offices can obtain the Consumer's Certificate of Exemption (Form DR-14) from University Tax Services or Purchasing or from county governmental offices.

\section{Paying State Tax on Items Sold by the 4-H Club or Affiliate}

When a 4-H club or affiliated group decides to sell specific items to others, they must collect sales tax on the sold items. This sales tax then needs to be transferred to the State of Florida.

Chapter 212 of the Florida Statutes define sales taxes as applying "...to the sale, rental, lease, or license to use goods, certain services, and commercial property in Florida, unless the transaction is specifically exempt."

Florida law provides that each sale, admission charge, storage, or rental is taxable unless the transaction is specifically exempt. Florida's general sales tax rate is $6 \%$; however, there is an established "bracket system" for collecting sales tax on any part of each total taxable sale that is less than a whole dollar amount. Additionally, a discretionary sales surtax is imposed by many Florida counties. To compute the Florida sales tax rate for each county, you add the county-imposed discretionary sales surtax rate to the general sales and use tax rate.

The University of Florida's tax-exempt status as a state agency does not extend to any other campus or professional organization under its auspices. County 4-H Foundations, clubs, affiliated 4-H organizations, and other IFAS entities must collect the appropriate sales tax on sales of food, property, or other items to the general public. County Extension Offices have the option of obtaining their own tax resale number, and must collect and report all taxes (percentage added to state $6 \%$ by county government) in their county. 
If your 4-H club or affiliated group plans to sell or resell any items, work very closely with the County Extension Director. This is one reason it is important for 4-H groups to be in close contact with the Extension Office when fund-raising efforts are planned.

\section{Resources}

USDA 4-H National Headquarters:

- Tax Exemption Status of 4-H Clubs and Affiliated 4-H Organizations:

http://www.national4-

hheadquarters.gov/library/fs_tax_4-05-

06.pdf

- Granting Authorization to use the 4-H Name and Emblem: http://www.national4hheadquarters.gov/library/fs_authorization_ 1-25-06.pdf

- Charters: The Key to Official Recognition: http://www.national4hheadquarters.gov/library/fs_charter_1-2506.pdf

IRS

- Application for Federal Employer Identification Number (SS-4): http://www.irs.gov/pub/irspdf/fss4.pdf?portlet=3

- Publication 78, Cumulative List of Organizations:

http://www.irs.gov/charities/article/0,,id=96 136,00.html

- Return of Organization Exempt From Income Tax (Form 990):

http://www.irs.gov/pub/irs-pdf/f990.pdf

Florida Department of Revenue

- Instructions for Completing Application for Consumer's Certificate of Exemption (Form DR-5):

http://www.myflorida.com/dor/forms/2003/d r5.pdf

- Florida Sales and Use Tax:

http://www.myflorida.com/dor/taxes/sales_t ax.html

UF IFAS Publications

- IMM: IFAS; Cash Receipts (7C1-6.40-13

(Revised):

http://imm.ifas.ufl.edu/6_40/640-13.htm 